Asian J. Med. Biol. Res. 2016, 2 (1), 19-26; doi: 10.3329/ajmbr.v2i1.27564

\author{
Asian Journal of \\ Medical and Biological Research \\ ISSN 2411-4472 (Print) 2412-5571 (Online) \\ www.ebupress.com/journal/ajmbr
}

\title{
Article \\ Evaluation of nutritive value and shelf life of strawberry genotypes
}

\author{
Sushan Chowhan ${ }^{1 *}$, Md. Shyduzzaman Roni ${ }^{2}$, Shaikh Shakib Ahmed ${ }^{3}$, Hanif Uddin ${ }^{4}$ and Md. Mahmudul Hasan ${ }^{5}$ \\ ${ }^{1}$ Bangladesh Institute of Nuclear Agriculture (BINA), Sub-station, Khagrachari, Bangladesh \\ ${ }^{2}$ Department of Horticulture, Bangabandhu Sheikh Mujibur Rahman Agricultural University, Gazipur, \\ Bangladesh \\ ${ }^{3} \mathrm{AB}$ Bank Ltd, Rangpur Branch, Bangladesh \\ ${ }^{4}$ Agriculture and Food Security Program, BRAC, Lalmonirhat, Bangladesh \\ ${ }^{5}$ Apex Organic Soya Industries Ltd., Sapmara, Gaibandha, Bangladesh
}

*Corresponding author: Sushan Chowhan, Scientific Officer, Bangladesh Institute of Nuclear Agriculture (BINA), Sub-station, Khagrachari, Bangladesh. E-mail: sushan04@yahoo.com

Received: 11 January 2016/Accepted: 08 March 2016/ Published: 31 March 2016

\begin{abstract}
An investigation was carried out to evaluate the nutritive value and shelf life of five strawberry genotypes. It was found that under fresh condition the highest ascorbic acid $(45.76 \mathrm{mg} / 100 \mathrm{~g})$ was obtained by Rabi-3 and the highest $\beta$-carotene (15.09 IU/100g) by Festival. The maximum amount of reducing sugar (6.373 $\mathrm{g} / 100 \mathrm{~g})$ and non-reducing sugar $(2.947 \mathrm{~g} / 100 \mathrm{~g})$ was recorded in Camarosa and Festival respectively. The maximum amount of calcium $(0.480 \%)$ in BADC Strawberry, iron (93.50 ppm) in Rabi-3, phosphorus $(0.081 \%)$ and potassium $(0.854 \%)$ in BARI Strawberry-1 was recorded. Under different temperature and packaging conditions, polyethylene package at $4^{0} \mathrm{C}$ proved to be superior to others in all respects. The highest shelf life (47.00 days) and ascorbic acid (42.76 mg/100g) after four days of storage was obtained by Camarosa in this condition; whereas the lowest shelf life (2.33 days) and ascorbic acid (10.12 mg/100g) was recorded in BADC Strawberry in plastic punnet package at $25^{\circ} \mathrm{C}$.
\end{abstract}

Keywords: nutritive value; shelf life; packaging; strawberry genotype

\section{Introduction}

Strawberries are widely grown fruit crop and adapted in geographically diverse area. For high yield and good quality fruits strawberry plants need about $20-26^{\circ} \mathrm{C}$ temperature in day and $12-16^{\circ} \mathrm{C}$ in night, with $8-12$ hours day length (Rebecca L. Darnell, 2003). It is one of the popular and most nutritious quick growing fruit. The nutritional value of strawberry is mainly due to the content of Vitamin C (Sanz et al., 1999). It contains 60 IU $\beta$ carotene (precursor of vitamin A), $30.0 \mathrm{mg}$ vitamin B and vitamin C 30-120 mg per 100g of edible portion with vitamin E, alagic acid, folic acid, fumaric acid, janthomycin and phytostebol (Anon, 2008). It also contains 0.55 percent pectin, $90.6 \mathrm{~g}$ water, $0.89 \mathrm{~g}$ protein, $0.5 \mathrm{~g}$ fat, $7.6 \mathrm{~g}$ carbohydrate and $1.7 \mathrm{~g}$ fibre per $100 \mathrm{~g}$ edible fruit (Rahman, 2011); potassium, calcium and phosphorus content being 7-12 percent (Jahan, 2010). Strawberries are highly perishable. As it is a non climacteric fruit, it must be picked at or near full ripen stage to obtain the best eating quality, they do not ripen off the plant. Their respiration rate is high (about $15 \mathrm{mg} / \mathrm{kg} / \mathrm{hr}$ at $0^{\circ} \mathrm{C}$ ) and increases 4 to 5 fold when temperature is elevated to $10^{\circ} \mathrm{C}$, between $10^{\circ} \mathrm{C}$ and $20^{\circ} \mathrm{C}$ the increase is 2 to 3 fold (Rosen and Kader, 1989). So its shelf life is very poor and thus needs immediate marketing after harvest. Delay in marketing results significant quality loss of the berries. Post harvest loss of fresh strawberry fruits is one of the problems in the tropics. In Bangladesh, a considerable amount of strawberry is being spoiled due to prevailing high temperature and humidity during harvesting period. There is lack of appropriate storage facilities and knowledge about storage is also insufficient. As a result, considerable quantity of strawberry is spoiled every year. The perishability of the fruits attributed to adverse physiological changes, namely, loss of weight due to respiration and transpiration, softening of flesh and loss of resistance capacity against microbial 
attack. Such spoilage causes considerable economic loss to both traders and retailers. Providing appropriate storage condition along with proper packaging materials is one of the important methods to reduce post harvest losses of strawberry. Therefore, the present investigation was carried out to find out optimum storage conditions for increasing the shelf life and to determine the nutritive value of strawberries under different storage conditions.

\section{Materials and Methods}

The investigation was carried out in the laboratory of the Department of Horticulture and Department of Soil Science, Bangabandhu Sheikh Mujibur Rahman Agricultural University (BSMRAU), Gazipur during the period from January to April, 2012. The experiment consisted of three factors. Five genotypes- Rabi-3, Camarosa, BARI Strawberry-1, BADC Strawberry and Festival were treated as factor A. Three storage conditions- Control or RT, $4^{\circ} \mathrm{C}$ and $12^{\circ} \mathrm{C}$ were treated as factor $\mathrm{B}$. Two packaging conditions- polyethylene package $(0.05 \mathrm{~mm}$ thickness $)$ and plastic punnet $(0.25 \mathrm{~mm}$ thickness $)$ were treated as factor $\mathrm{C}$. The experiment was laid out in factorial completely randomized design (CRD) with three replications. Data on ascorbic acid (mg/100g), $\beta$ Carotene $(\mathrm{IU} / 100 \mathrm{~g})$, reducing sugar $(\mathrm{g} / 100 \mathrm{~g})$, total sugar $(\mathrm{g} / 100 \mathrm{~g})$ and non reducing sugar $(\mathrm{g} / 100 \mathrm{~g})$ was recorded immediate after harvesting of the fruits. Calcium (\%), Iron (\%), Phosphorus (\%) and Potassium (\%) were determined from the oven dried samples. Shelf life (days) and ascorbic acid (mg/100g) content under different treatments was also recorded. Shelf life (days) of strawberry fruits under different temperatures $\left(4^{0} \mathrm{C}\right.$, $12^{\circ} \mathrm{C}, \mathrm{RT}$ ) and packaging conditions (polyethylene pack and plastic punnet) were measured by initiation of any objectionable symptom (like microbial infection, colour change, objectionable odor etc.) which was observed by eye estimation. Changes in ascorbic acid content under different temperature and packaging conditions were determined four days after putting into storage. Ascorbic acid content was determined as per the procedure described by Pleshkov (1976). For $\beta$-Carotene estimation, one gram of sample was crushed and mixed thoroughly with $10 \mathrm{~mL}$ acetone: hexane (4:6) solution. This sample was centrifuged and optical density of the

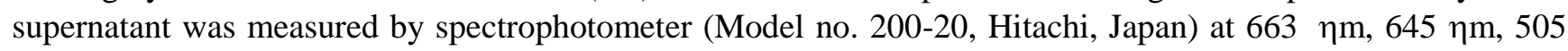
$\eta \mathrm{m}$ and $453 \eta \mathrm{m}$. Calculation was done according to the formula of Nagata et al. (1992). Reducing, nonreducing and total sugars were estimated as per the procedure described by Somogyi (1952) using Bertrand A, Bertrand B and Bertrand C solutions. Dried plant materials were digested with concentrated $\mathrm{HNO}_{3}$ and $\mathrm{HClO}_{4}$ mixture as described by Piper (1966) for determination of total calcium, iron, phosphorus and potassium content. Calcium, iron and potassium extract readings were taken in atomic absorption spectrophotometer (Model no. 170-30, Hitachi, Japan) at wavelength of $422.8 \eta \mathrm{m}, 248.3 \eta \mathrm{m}$ and $766.5 \eta \mathrm{m}$ respectively. Total phosphorous contain in the extract was determined by Vanadomolybdate yellow colour method as described by Jackson (1973). The absorbance was measured at $440 \eta \mathrm{m}$ wavelength by a double beam spectrophotometer (Model no. 200-20, HITACHI, Japan). The collected data on various parameters were statistically analyzed using MSTAT-C program and the significance was tested by ANOVA. The means of different parameters were compared by Duncan's Multiple Range Test (DMRT) at 1\% or 5\% level of probability (Gomez and Gomez 1984).

\section{Results and Discussion}

The results obtained from the present investigation have been presented and discussed character wise under separate headings.

\subsection{Ascorbic acid}

Variation in free ascorbic acid among the genotypes was statistically significant (Table 1). It ranged between 35.21 and $45.76 \mathrm{mg} / 100 \mathrm{~g}$. The highest content of free ascorbic acid was recorded in Rabi-3; which was statistically identical to Camarosa and Festival. The lowest was in BADC Strawberry; which was statistically identical to BARI Strawberry-1. In a study Zmuda et al. (2004) found highest $60 \mathrm{mg}$ ascorbic acid among 23 strawberry cultivars. The above finding is less than that; this was mainly due to climatic and environmental factors.

\section{2. $\beta$-carotene}

Significant variations in the amount of $\beta$-carotene were found, when considered different genotype effect. It varied from 9.56 to $15.09 \mathrm{IU} / 100 \mathrm{~g}$ (Table 1). Festival had the maximum amount of $\beta$-carotene (15.09 IU/100g) followed by BADC Strawberry. Camarosa had the lowest amount of $\beta$-carotene (9.56 IU/100g) which was 
statistically identical to BARI Strawberry-1. Variations in $\beta$-carotene was mainly due to inherent characteristics of the genotype, climatic and environmental factors.

\subsection{Reducing sugar}

Amount of reducing sugar content (Table 2) among the genotypes was significant. Highest content (6.373 $\mathrm{g} / 100 \mathrm{~g})$ of reducing sugar was found in Camarosa and the lowest $(3.383 \mathrm{~g} / 100 \mathrm{~g})$ was in Festival; which was statistically different to Rabi-3, BARI Strawberry-1 and BADC Strawberry. Skupien (2003) reported that reducing sugar content in strawberry cultivars were $5.99 \mathrm{~g} / 100 \mathrm{~g}$. Which was more or less close to the present findings.

Table 1. Ascorbic acid and $\beta$-carotene content of freshly harvested strawberries.

\begin{tabular}{lll}
\hline Genotypes & Ascorbic acid (mg/100g) & $\beta$-carotene (IU/100g) \\
\hline Rabi-3 & $45.76 \mathrm{a}$ & $13.68 \mathrm{ab}$ \\
Camarosa & $44.73 \mathrm{a}$ & $9.56 \mathrm{c}$ \\
BARI Strawberry-1 & $36.36 \mathrm{~b}$ & $9.67 \mathrm{c}$ \\
BADC Strawberry & $35.21 \mathrm{~b}$ & $12.22 \mathrm{~b}$ \\
Festival & $44.00 \mathrm{a}$ & $15.09 \mathrm{a}$ \\
\hline Level of Significance & $* *$ & $* *$ \\
CV \% & 2.42 & 6.31 \\
\hline
\end{tabular}

Means bearing same letter(s) in a column do not differ significantly at $1 \%$ level of probability by DMRT.

\subsection{Non reducing sugar}

Non reducing sugar content was significant (Table 2) among the genotypes. Maximum amount (2.947 g/100g) of non reducing sugar was recorded in Festival and the minimum $(2.310 \mathrm{~g} / 100 \mathrm{~g})$ was in $\mathrm{V}_{1}(\mathrm{Rabi}-3)$ which was statistically different to Camarosa, BARI Strawberry-1 and BADC Strawberry. Skupien (2003) reported that non reducing sugar content in different strawberry cultivars were $1.61 \mathrm{~g} / 100 \mathrm{~g}$. The amount of non reducing sugar from the investigation was more; this variation was mainly due to genotype, climate and local environmental conditions.

\subsection{Total sugar}

Highest amount $(8.480 \mathrm{~g} / 100 \mathrm{~g})$ of total sugar (Table 2) was found in Camarosa which was statistically identical to Rabi-3, BARI Strawberry-1 and BADC Strawberry. Genotype Festival had the lowest $(6.330 \mathrm{~g} / 100 \mathrm{~g})$ total sugar content and was statistically different to all the four genotypes. Variation in total sugar was might be due to climatic and genetic factors. Zmuda et al. (2004) and Skupien (2003) reported that total sugar content in different strawberry cultivars ranged from $6.21 \mathrm{~g} / 100 \mathrm{~g}$ to $7.60 \mathrm{~g} / 100 \mathrm{~g}$; which was more or less close to the present findings.

Table 2. Sugar content of five strawberry genotypes.

\begin{tabular}{llll}
\hline Genotypes & Reducing $(\mathbf{g} / \mathbf{1 0 0 g})$ & Non reducing $(\mathbf{g} / \mathbf{1 0 0 g})$ & Total $(\mathbf{g} / \mathbf{1 0 0 g})$ \\
\hline Rabi-3 & $6.170 \mathrm{a}$ & $2.310 \mathrm{c}$ & $8.480 \mathrm{a}$ \\
Camarosa & $6.373 \mathrm{a}$ & $2.667 \mathrm{~b}$ & $9.040 \mathrm{a}$ \\
BARI Strawberry-1 & $6.033 \mathrm{a}$ & $2.677 \mathrm{~b}$ & $8.710 \mathrm{a}$ \\
BADC Strawberry & $6.003 \mathrm{a}$ & $2.700 \mathrm{~b}$ & $8.703 \mathrm{a}$ \\
Festival & $3.383 \mathrm{~b}$ & $2.947 \mathrm{a}$ & $6.330 \mathrm{~b}$ \\
\hline Level of Significance & $* *$ & $*$ & $* *$ \\
CV \% & 10.07 & 5.09 & 6.90 \\
\hline
\end{tabular}

Means bearing same letter(s) in a column do not differ significantly at 1 or $5 \%$ level of probability by DMRT.

\subsection{Calcium}

Significant variation in calcium content (Table 3) was observed among the genotypes. Highest $(0.480 \%)$ calcium was found in BADC Strawberry which was statistically similar to Rabi-3 and lowest $(0.373 \%)$ was in Festival; which was statistically same to the genotypes Camarosa and BARI Strawberry-1. 


\subsection{Iron}

Differences in iron content (Table 3) were significant. Rabi-3 had the highest (93.50 ppm) iron which was almost equal to $(90.95 \mathrm{ppm})$ Camarosa. BARI Strawberry-1 had the lowest $(77.78 \mathrm{ppm})$ iron content which was statistically similar to the two genotypes BADC Strawberry and Festival.

Table 3. Mineral content of five strawberry genotypes.

\begin{tabular}{lllll}
\hline Genotypes & Ca $(\%)$ & Fe $(\mathbf{p p m})$ & $\mathbf{P}(\boldsymbol{\%})$ & $\mathbf{K}(\%)$ \\
\hline Rabi-3 & $0.469 \mathrm{ab}$ & $93.50 \mathrm{a}$ & $0.075 \mathrm{~b}$ & $0.835 \mathrm{~d}$ \\
Camarosa & $0.410 \mathrm{bc}$ & $90.95 \mathrm{a}$ & $0.072 \mathrm{c}$ & $0.836 \mathrm{~d}$ \\
BARI Strawberry-1 & $0.410 \mathrm{c}$ & $77.78 \mathrm{~b}$ & $0.081 \mathrm{a}$ & $0.854 \mathrm{a}$ \\
BADC Strawberry & $0.480 \mathrm{a}$ & $86.13 \mathrm{ab}$ & $0.081 \mathrm{a}$ & $0.838 \mathrm{c}$ \\
Festival & $0.373 \mathrm{c}$ & $82.88 \mathrm{ab}$ & $0.073 \mathrm{c}$ & $0.844 \mathrm{~b}$ \\
\hline Level of Significance & $*$ & $*$ & $*$ & $*$ \\
CV \% & 7.53 & 6.71 & 8.62 & 1.53 \\
\hline
\end{tabular}

Means bearing same letter(s) in a column do not differ significantly at $5 \%$ level of probability by DMRT.

\subsection{Phosphorus}

There was a significant variation in phosphorus content (Table 3) among all the genotypes. It ranged between $0.072 \%$ and $0.081 \%$. The maximum content of phosphorus was recorded in BARI Strawberry-1 and BADC Strawberry. The lowest was in Camarosa which was statistically identical to Festival.

\subsection{Potassium}

Potassium content (Table 3) was also significantly different among the genotypes. Highest amount of potassium $(0.854 \%)$ was found in BARI Strawberry-1 followed by Festival and BADC Strawberry. Lowest $(0.835 \%)$ was in Rabi-3 which was statistically identical to Camarosa.

Shelf life also differed among the genotypes due to various temperature and packaging conditions (Table 4). Highest shelf life (26.88 days) was obtained at $4^{0} \mathrm{C}$ in polyethylene package condition and lowest (4.23 days) was recorded at RT in plastic punnet packaging; which was statistically identical to the polyethylene packaging at RT. Low temperature prolongs and high temperature lowers shelf life. Plastic punnets were unsealed as a result microbial infection, water loss was higher; polyethylene packages were slightly wrapped and thus reduced the water loss and infection; which consequently increased the shelf life. Krivorot and Dris (2002) reported that, packing strawberries in polyethylene bags decreased respiration, maintained quality, and prolonged the shelf life for 20-25 days in different cultivars.

Table 4. Shelf life of strawberry genotypes influenced by different temperature and packaging

\begin{tabular}{ccc}
\hline \multirow{2}{*}{ Temperature } & \multicolumn{2}{c}{ Shelf life (days) } \\
\cline { 2 - 3 } & Polyethylene package & Plastic punnet \\
\hline $4^{0} \mathrm{C}$ & $26.88 \mathrm{a}$ & $18.43 \mathrm{~b}$ \\
$12^{0} \mathrm{C}$ & $20.46 \mathrm{~b}$ & $4.84 \mathrm{c}$ \\
$\mathrm{RT}$ & $5.83 \mathrm{~d}$ & $4.23 \mathrm{~d}$ \\
\hline CV $\%$ & & $* *$ \\
\hline
\end{tabular}

Means bearing same letter(s) in a column do not differ significantly at $1 \%$ level of probability by DMRT.

Table 5. Shelf life of strawberry genotypes due to interaction effect of genotype, temperature and packaging.

\begin{tabular}{|c|c|c|c|c|c|c|}
\hline \multirow{2}{*}{ Genotypes } & \multicolumn{3}{|c|}{ Polyethylene package } & \multicolumn{3}{|c|}{ Plastic punnet } \\
\hline & $4^{0} \mathrm{C}$ & $12^{0} \mathrm{C}$ & RT & $4^{0} \mathrm{C}$ & $12^{0} \mathrm{C}$ & RT \\
\hline Rabi-3 & $14.89 \mathrm{hi}$ & $14.13 \mathrm{i}$ & $4.25 \mathrm{~lm}$ & 15.96 ghi & $11.46 \mathrm{j}$ & $4.00 \mathrm{~lm}$ \\
\hline Camarosa & $47.00 \mathrm{a}$ & $29.33 \mathrm{~b}$ & 6.081 & 19.00 ef & $17.00 \mathrm{fgh}$ & 6.001 \\
\hline BARI Strawberry-1 & $26.33 \mathrm{c}$ & $15.50 \mathrm{ghi}$ & 5.001 & $22.83 \mathrm{~d}$ & 6.501 & $6.50 \mathrm{kl}$ \\
\hline BADC Strawberry & $26.67 \mathrm{c}$ & $28.00 \mathrm{bc}$ & 5.001 & $17.33 \mathrm{e}-\mathrm{h}$ & 6.501 & $2.33 \mathrm{~m}$ \\
\hline Festival & $19.50 \mathrm{e}$ & $15.33 \mathrm{ghi}$ & $8.83 \mathrm{k}$ & $17.00 \mathrm{fgh}$ & $17.75 \mathrm{efg}$ & $2.33 \mathrm{~m}$ \\
\hline Level of Significance & \multicolumn{6}{|c|}{$* *$} \\
\hline $\mathrm{CV} \%$ & \multicolumn{6}{|c|}{6.98} \\
\hline
\end{tabular}

Means bearing same letter(s) in a column do not differ significantly at $1 \%$ level of probability by DMRT. 
Combined effects of genotype, temperature and packaging had a significant variation on the shelf life of different strawberry genotypes (Table 5). Longest (47.00 days) shelf life was obtained by Camarosa; which was statistically larger than other four genotypes at $4^{0} \mathrm{C}$ and shortest ( 4.25 days) was obtained by Rabi-3 under polyethylene packaging; which was statistically similar to BADC Strawberry, BARI Strawberry-1 and Camarosa at RT. On the other hand under plastic punnet packaging, longest (22.83 days) shelf life was also obtained by BARI Strawberry-1; which was statistically greater than any other genotypes at $4^{0} \mathrm{C}$ and the shortest (2.33 days) shelf life was obtained by the genotypes BADC Strawberry and Festival which was statistically similar to Rabi-3 at RT. The reason of variation in the shelf life was mainly due to inherent genetic characteristics of the genotypes, different temperature and packaging conditions. Rahman and Ahmad (2010) reported that, shelf life (days) of strawberries under RT varied from 1.5 to 3.5 days.

Table 6. Ascorbic acid content of strawberry genotypes influenced by different temperature and packaging.

\begin{tabular}{lll}
\hline \multirow{2}{*}{ Genotype } & \multicolumn{2}{c}{ Ascorbic acid (mg/100g) content } \\
\cline { 2 - 3 } & Polyethylene package & Plastic punnet \\
\hline Rabi-3 & $32.72 \mathrm{ab}$ & $30.59 \mathrm{~b}$ \\
Camarosa & $34.74 \mathrm{a}$ & $32.49 \mathrm{ab}$ \\
BARI Strawberry-1 & $24.35 \mathrm{c}$ & $22.85 \mathrm{~cd}$ \\
BADC Strawberry & $22.55 \mathrm{~cd}$ & $20.65 \mathrm{~d}$ \\
Festival & $35.42 \mathrm{a}$ & $33.52 \mathrm{a}$ \\
\hline Level of Significance & & $* *$ \\
\hline CV \% & \multicolumn{2}{c}{4.34} \\
\hline
\end{tabular}

Means bearing same letter(s) in a column do not differ significantly at $1 \%$ level of probability by DMRT.

Ascorbic acid content among the genotypes differed due to various temperature and packaging conditions (Table 6). Maximum ascorbic acid $(38.51 \mathrm{mg} / 100 \mathrm{~g})$ was obtained at $4^{0} \mathrm{C}$ in polyethylene packaging condition and minimum $(16.66 \mathrm{mg} / 100 \mathrm{~g})$ was recorded at RT in plastic punnet packaging; which was statistically different to the polyethylene and plastic punnet packaging for $4^{0} \mathrm{C}$ and RT. Yamashita et al. (1993) reported that ascorbic acid content decreased drastically after transfer to $30^{\circ} \mathrm{C}$ when strawberries were packed with polythene film pouch of thickness $0.03 \mathrm{~mm}$; which more or less supported the above finding.

Combined effects of genotype, temperature and packaging had a significant variation on the ascorbic acid content of different strawberry genotypes (Table 7.). Highest $(42.76 \mathrm{mg} / 100 \mathrm{~g})$ ascorbic acid was obtained by Camarosa; which was statistically identical to Rabi-3 and Festival at $4^{0} \mathrm{C}$ and lowest $(12.17 \mathrm{mg} / 100 \mathrm{~g})$ was obtained by BADC Strawberry under polyethylene packaging at RT. On the other hand under plastic punnet packaging, highest $(41.75 \mathrm{mg} / 100 \mathrm{~g})$ ascorbic acid was obtained by Festival; which was statistically identical to Camarosa and Rabi-3; and was significantly greater than the other genotypes at $4^{0} \mathrm{C}$. The lowest $(10.12$ $\mathrm{mg} / 100 \mathrm{~g}$ ) ascorbic acid was obtained by the genotype BADC Strawberry; which was statistically identical to BARI Strawberry-1 at RT. Munbodh and Goburdhun (2001) reported that strawberries stored under non perforated punnets kept at $0^{\circ} \mathrm{C}$ had a lower percentage of weight loss, fruit shriveling and retained vitamin $\mathrm{C}$ level. From the above investigation it was found that, the reason of large variation in the ascorbic acid content was mainly due to different temperature and packaging conditions.

Table 7. Ascorbic acid content of strawberry genotypes due to interaction effect of genotype, temperature and packaging.

\begin{tabular}{|c|c|c|c|c|c|c|}
\hline \multirow{2}{*}{ Genotypes } & \multicolumn{3}{|c|}{ Polyethylene package } & \multicolumn{3}{|c|}{ Plastic punnet } \\
\hline & $4^{0} \mathrm{C}$ & $12^{0} \mathrm{C}$ & RT & $4^{0} \mathrm{C}$ & $12^{0} \mathrm{C}$ & RT \\
\hline Rabi-3 & $42.44 \mathrm{a}$ & $35.42 \mathrm{bc}$ & $20.31 \mathrm{jk}$ & $41.32 \mathrm{a}$ & 32.41 cde & $18.04 \mathrm{k}$ \\
\hline Camarosa & $42.76 \mathrm{a}$ & $37.11 \mathrm{~b}$ & $24.35 \mathrm{fg}$ & $41.58 \mathrm{a}$ & $35.20 \mathrm{bc}$ & $20.68 \mathrm{ijk}$ \\
\hline BARI Strrawberry-1 & $33.44 \mathrm{~cd}$ & $25.76 \mathrm{fg}$ & 13.861 & 32.46 cde & $25.08 \mathrm{fg}$ & $11.00 \mathrm{~m}$ \\
\hline BADC Strawberry & $31.74 \mathrm{de}$ & $23.73 \mathrm{gh}$ & $12.17 \mathrm{~lm}$ & $30.41 \mathrm{e}$ & 21.41 hij & $10.12 \mathrm{~m}$ \\
\hline Festival & $42.16 \mathrm{a}$ & $36.96 \mathrm{~b}$ & $27.13 \mathrm{f}$ & $41.75 \mathrm{a}$ & $35.35 \mathrm{bc}$ & $23.47 \mathrm{ghi}$ \\
\hline Level of Significance & & & & & & \\
\hline
\end{tabular}

Means bearing same letter(s) in a column do not differ significantly at $1 \%$ level of probability by DMRT. 


\subsection{Shelf life under different treatments}

Strawberry genotypes had a significant influence on the shelf life of berries (Figure 1). The genotype Camarosa had the longest (20.74 days) shelf life followed by (BADC Strawberry, BARI Strawberry-1 and Festival. Shortest shelf life (10.78 days) was obtained by Rabi-3. This was might be due to the inherent control of the genotypes.

Shelf life was also greatly affected by various temperature treatments. At $4^{0} \mathrm{C}$ highest shelf life was 22.65 days; while in RT temperature the shelf life was reduced to 5.03 days (Figure 2). Low temperature reduces respiration, slows the metabolic activity of cells thus $4^{0} \mathrm{C}$ provided better shelf life. Rahman and Ahmad (2010a) reported that, under room temperature (RT) shelf life ranged between 1.4 to 3.5 days in different strawberry genotypes.

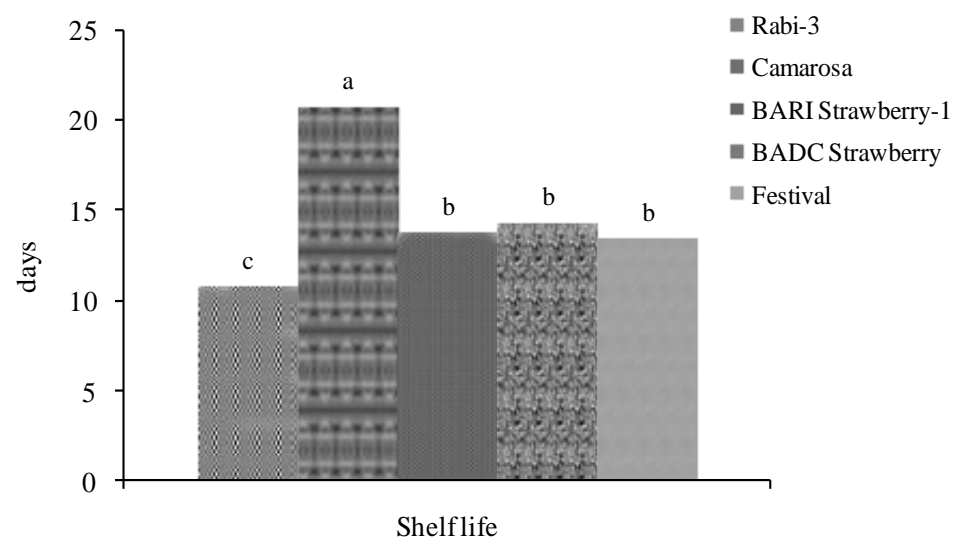

Figure 1. Shelf life influenced by strawberry genotypes.

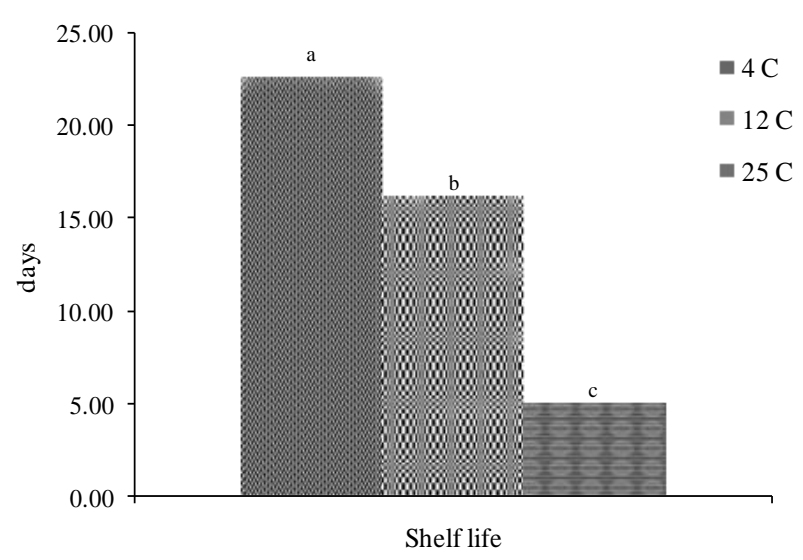

Figure 2. Shelf life of strawberry genotypes influenced by different temperatures.

\subsection{Ascorbic acid content under different treatments}

Strawberry genotypes had a significant influence on the ascorbic acid content of berries (Figure 3). The genotype Festival had the highest $(34.47 \mathrm{mg} / 100 \mathrm{~g})$ ascorbic acid followed by Camarosa, Rabi-3 and BARI Strawberry-1. Lowest ascorbic acid $(21.60 \mathrm{mg} / 100 \mathrm{~g})$ was obtained by BADC Strawberry. This was might be due to the inherent control of the genotypes.

Ascorbic acid content was also greatly affected by various temperature treatments (Figure 4). At $4^{0} \mathrm{C}$ maximum ascorbic acid was $38.01 \mathrm{mg} / 100 \mathrm{~g}$; while in RT temperature the ascorbic acid was reduced to $18.11 \mathrm{mg} / 100 \mathrm{~g}$. Ascorbic acid is a heat sensitive element thus in high temperature it was reduced. 


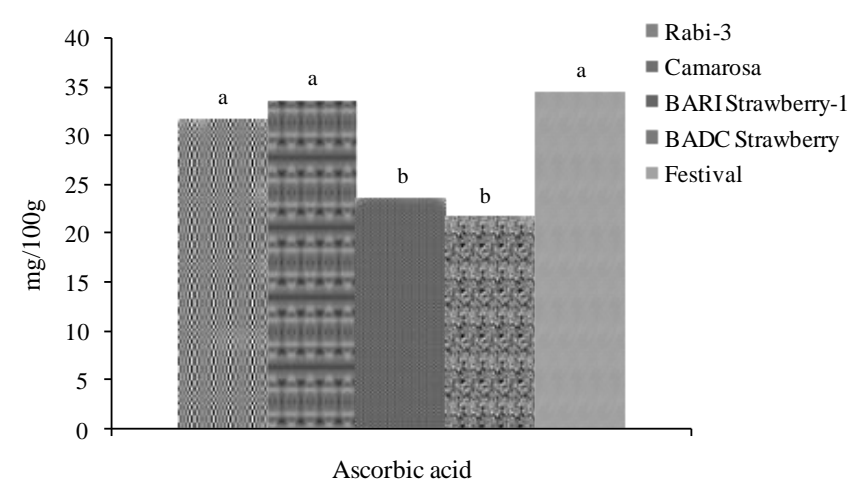

Figure 3. Ascorbic acid content influenced by strawberry genotypes.

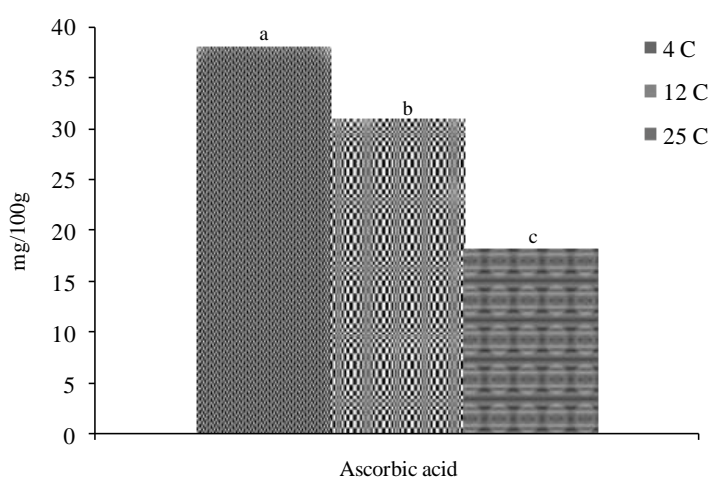

Figure 4. Ascorbic acid content of strawberry genotypes influenced by different temperatures.

\section{Conclusions}

On the basis of the obtained results, it may be concluded that, nutritional status such as ascorbic acid, $\beta$ carotene, sugar, calcium, iron, and phosphorus of strawberry varied significantly, this might be due to the genotypic and climatic variations. Potassium content was not influenced by genotypes; it was more or less equal in all cases. Strawberries kept in polyethylene packages at $4^{0} \mathrm{C}$ temperature provided maximum shelf life. Percent loss of ascorbic acid is comparatively lower when strawberries are stored at this temperature in polyethylene packaging.

\section{Conflict of interest}

None to declare.

\section{References}

Anonymous, 2008. Bangladesh: Strawberry Farming Gains Popularity in Northern Region. The New Nation, 12 November, 2008.

Gomez KA and AA Gomez, 1984. Statistical Procedures for Agricultural Research. (2 ${ }^{\text {nd }}$ Edition). John Willy and Sons, New York. pp. 28-192.

Jahan N, 2010. Shelf life extension of Strawberry (Fragaria ananassa). An unpublished MS Thesis. Department of Horticulture, Bangladesh Agricultural University, Mymensingh-2202. pp. 1-92.

Krivorot AM and R Dris, 2002. Shelf life and quality changes of strawberry cultivars. Acta. Hortic., 567: 755758.

Munbodh RS and S Goburdhun, 2001. Effect of temperature and packaging on shelf life of two strawberry cultivars (Marquise and Tiobelle). Revue Agricole et Sucriere-de-l'-Ile Maurice. 80/81(3-1/3): 171-178.

Nagata M, K Dan and I Yamashita, 1992. Simple methods for simultaneous determination of chlorophyll and carotenoiods in tomato. J. Jpn. Soc. Hortic. Sci., 61: 685-687.

Piper CS, 1966. Soil and Plant Analysis. Hans Publishers, Bombay (Reprint). pp. 368-392.

Pleshkov BP, 1976. Practical works on plant biochemistry. Moscow, Kolos. pp. 236-238.

Rahman L, 2011. Production technology of strawberry in Bangladesh. An unpublished Ph.D. Thesis. Department of Horticulture, Bangabandhu Sheikh Mujibur Rahman Agricultural University, Salna, Gazipur1706. pp. 1-162. 
Rahman MM and MR Ahmad, 2010. Regional Yield Trial of Strawberry Lines. Research Report on Horticultural Crops. BARI, Joydebpur, Gazipur-1701. pp. 332-333.

Rahman MM and MR Ahmad, 2010a. Collection and Evaluation of Strawberry Lines. Research Report on Horticultural Crops. BARI, Joydebpur, Gazipur-1701. pp. 329-331.

Rebecca L. Darnel, 2003. Strawberry growth and development. In: The Strawberry, A Book for Growers, Others. eds. Norman F. Childer. 3906 N.W. $31^{\text {st }}$ Place, Florida. pp. 3-10.

Rosen J and AA Kader, 1989. Postharvest physiology and quality maintenance of sliced pear and strawberry fruits. J. Food Sci., 54: 656-659.

Sanz C, AG Perez, R. Olias and JM Olias, 1999. Quality of strawberries packed with perforated polypropylene. Journal of Food Science, 64:748-752.

Skupien K, 2003. Biological value of selected cultivars of strawberry fruit (Fragariaxananassa Duch.). Folia Horticulturae. Krakow, Poland: Pol. Soc. Hortic. Sci., 15: 167-172.

Somogyi M, 1952. Notes on sugar determination. J. Biol. Chem., 195: 19-23.

Yamashita I, M Nagata, L Gao and T Kurogi, 1993. Influence of temperature on quality of broccoli under modified atmosphere packaging. J. Japanese Soc. Food Sci. Tec., 10: 764-770.

Zmuda E, J Wieniarska and E Szember, 2004. Comparative studies on chemical composition of chosen strawberries cultivars (Fragaria $\times a n a n a s s a$ Duch.). Folia Universitatis Agriculturae Stetinensis, Agricultura. Katedra Sadownictwa, Akademia Rolnicza, Poland. 96: 225-230. 